\title{
DISCOVERY OF PUCCINIA TILIAEFOLIA (PUCCINIALES) IN NORTHWESTERN HIMALAYAS, INDIA
}

\author{
Ajay Kumar Gautam ${ }^{1} \&$ Shubhi Avasthi
}

\begin{abstract}
A rust infection was recently observed on Grewia tiliifolia Vahl during an exploration of rust fungi in Himachal Pradesh, India, in October 2015. An examination identified the rust fungus as Puccinia tiliaefolia T. S. Ramakr. \& Sundaram. This finding represents a new record for the northwestern Himalayas and the first finding of Puccinia tiliaefolia in India in the last 46 years. A geographical distribution map of $P$. tiliaefolia is presented.
\end{abstract}

Key words: Asia, distribution, Himalayas, Indian Subcontinent, Puccinia, rust fungi

Ajay Kumar Gautam, Faculty of Science, School of Agriculture, Abhilashi University, Mandi, Himachal Pradesh, India; e-mail: a2gautam2006@gmail.com

Shubhi Avasthi, Department of Botany, Abhilashi Post Graduate Institute of Sciences, Mandi, Himachal Pradesh, India

\section{INTRODUCTION}

The genus Puccinia Pers. (Pucciniales, Pucciniaceae) contains $c a 4000$ obligatory plant-pathogenic species (Farr \& Rossman 2016), which infect a wide range of host plants including agricultural crops as well as non-agricultural plants. The genus Puccinia is the most speciose of the estimated 168 rust genera and $c a 7000$ species known in the world. Herbarium Cryptogamae Indiae Orientalis (HCIO), a national herbarium of India, has prepared a checklist of Puccinia species preserved in the herbarium. It lists a vast collection containing 718 species from a range of host plant families (Kamil et al. 2013). Recently, Gautam and Avasthi (2016) published a checklist of rust fungi belonging to the genus Puccinia for Himachal Pradesh, and recorded 80 species infecting 91 host plant species and 33 host plant families. The family Poaceae was reported to be most commonly infected, with 26 species of Puccinia.

In the winter season (October 2015), a rust infection on leaves of Grewia tiliifolia Vahl was observed during an exploration of rust fungi in Himachal Pradesh. The examination of disease symptoms and morphological and microscopic

\footnotetext{
1 Corresponding author
}

characters of the pathogen identified this fungus as Puccinia tiliaefolia T. S. Ramakr. \& Sundaram.

Puccinia tiliaefolia was established by Ramakrishnan and Sundaram (1955) based on a collection of a rust infecting Grewia tiliifolia in southern India. This rust fungus is characterized by 1-celled dikaryotic urediniospores (in uredinia), diploid 2-celled teliospores (in telia), and globose basidiospores borne on sterigmata. The current finding of Puccinia tiliaefolia in Himachal Pradesh constitutes a new record for the northwestern Himalayas and a rediscovery of the species after 46 years without such a record in India. Species descriptions along with distributional notes are provided here.

\section{Material AND METHODS}

The infected plant leaves showing rust symptoms were collected during a mycological survey of Mandi District of Himanchal Pradesh, India, during October 2015. Field observations, infection symptoms and the colony morphology of the rust fungus on the host plant were noted during the collection event. Air-dried specimens were preserved in herbarium packets and on a herbarium sheet, and deposited in the Abhilashi University Mycological Herbarium (AUMH). 


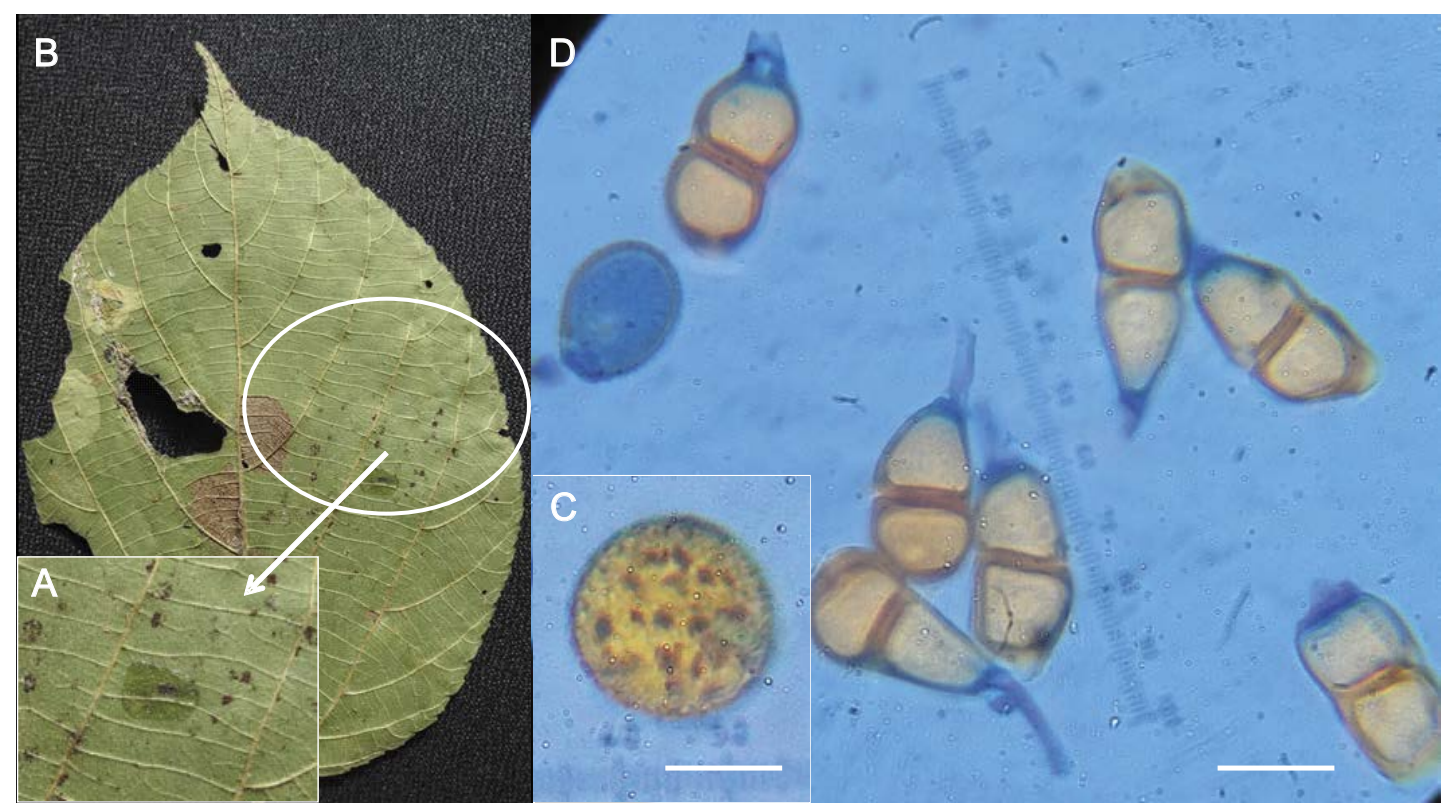

Fig. 1. Puccinia tiliaefolia T. S. Ramakr. \& Sundaram on Grewia tiliifolia Vahl. A \& B - telia (encircled and enlarged view), $\mathrm{C}$ - urediospore, $\mathrm{D}$ - teliospores. Scale bars: $\mathrm{C}=10 \mu \mathrm{m}, \mathrm{D}=20 \mu \mathrm{m}$.

Microscope slides were prepared from fresh samples by mounting the rust powder in a drop of distilled water and Lactophenol Cotton Blue mount mixture. The spore characteristics were observed from such prepared slides. The fungal specimens were identified and their distributional records were checked in the standard literature (Bilgrami et al. 1991; Cummins \& Hiratsuka 2003; Jamaluddin et al. 2004). Illustrations were prepared and photographed under an Olympus $\mathrm{CH} 2$ light microscope fitted with a Sony DSC 1500 digital camera.

\section{RESULTS AND DISCUSSION}

\section{Puccinia tiliaefolia T. S. Ramakr. \& Sundaram} Figs $1 \& 2$

Proc. Indian Acad. Sci., B 41(5): 194. 1955.

Telia hypophyllous, minute, scattered, erumpent, pulvinate, brown, gregarious, several adjacent telia coalesce to form compact groups $0.2-0.5 \mathrm{~mm}$ in diameter. Teliospores oblong or obclavate, elliptical, brown, 2-celled, apex almost rounded, sometimes thickened (up to $4.5 \mu \mathrm{m}$ ), slightly constricted at septum, 20-42 × 10-17 (average $27 \times 15) \mu \mathrm{m}$, wall $2.0-2.5 \mu \mathrm{m}$ thick at sides, pedicels colourless, up to $65 \mu \mathrm{m}$ long, fragile.
Mesospores (3-celled spores) not found. Uredinia not observed, but in LM some urediospores seen to be borne singly on pedicel and mostly echinulate, with germ pores various. This indicates that

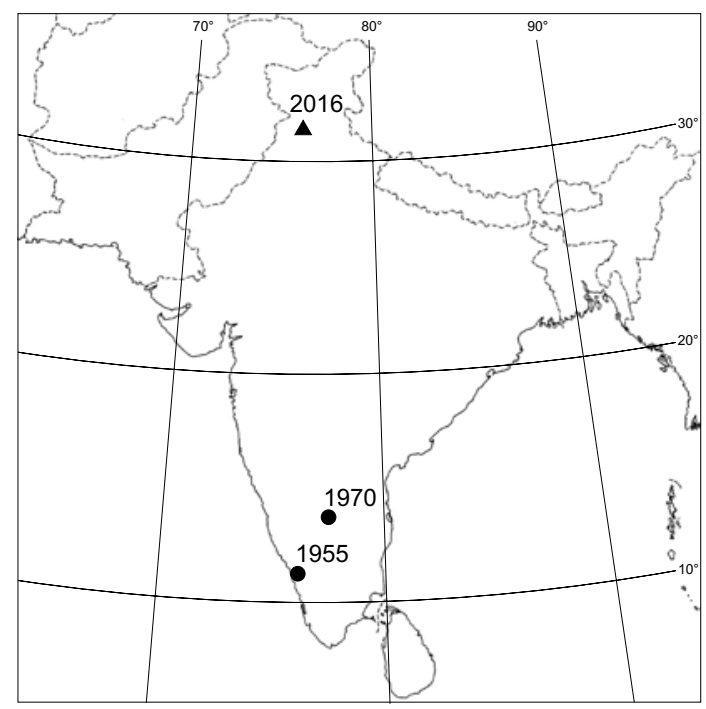

Fig. 2. Distribution map for Puccinia tiliaefolia T. S. Ramakr. \& Sundaram in India ( $\boldsymbol{\Delta}$ - current report). 
the telia and uredia are mixed during the growth and development of the rust fungus.

Material examined: INDIA, Himachal Pradesh, Mandi, $760 \mathrm{~m}$, on leaves of Grewia tiliifolia (Malvaceae), 26 Oct. 2015, A.K. Gautam (AUMH 135).

Notes. According to the literature, Puccinia tiliaefolia was first described from Ambalovayal (Malabar), Madras, Tamil Nadu (now in Kerala) by Ramakrishnan and Sundaram (1955) and later found in the Nandi Hills (Karnataka) by Rangaswami et al. (1970) (Fig. 2). Previously ca 33 host plant families were reported to be infected by Puccinia species in Himachal Pradesh, but there was no rust reported on host plants in the family Malvaceae. Except for two records in southern India mentioned above, no other report of $P$. tiliaefolia was published from any part of the country. This is the first report of $P$. tiliaefolia from the northwestern Himalayas, and a new addition to the rust fungi of the region. This discovery extends the geographical range of Puccinia tiliaefolia in India.

Acknowledgements. We are grateful to Dr. R. C. Thakur (Dean, Faculty of Sciences, Abhilashi University) and Dr. Suresh Kumar (Head, Department of Botany, Abhilashi Post Graduate Institute of Sciences) Mandi, Himachal Pradesh, India, for providing the necessary laboratory facilities and valuable support during the study. We thank the anonymous reviewers for their critical comments and suggestions.

\section{REFERENCES}

Bilgrami K. S., Jamaluddin M. A. \& Rizwi M. A. 1991. The Fungi of India. Part III (List and References). Today and Tomorrow's Printer and Publishers, New Delhi.

Cummins G. B. \& Hiratsuka Y. 2003. Illustrated genera of rust fungi, 3rd ed. APS Press, St. Paul.

Farr D. F. \& Rossman A. Y. 2016. Fungal Databases, Systematic Mycology and Microbiology Laboratory, ARS, USDA [30 April 2016]. http://nt.ars-grin.gov/fungaldatabases/

Gautam A. K. \& Avasthi S. 2016. First checklist of rust fungi in the genus Puccinia from Himachal Pradesh, India. Plant Pathology \& Quarantine 6(2): 114-128.

Jamaluddin, Goswami M. G. \& OJHA B. M. 2004. Fungi of India (1989-2001). Scientific Publishers, Jodhapur.

Kamil D., Sharma R. K., Uma Masheswari C., Prameela Devi T. \& JaIN R. K. 2013. HCIO - Herbarium Cryptogamae Indiae Orientalis, Check List of Puccinia species. Indian Agricultural Research Institute, New Delhi, India.

Ramakrishanan T. S. \& Sundaram N. V. 1955. Additions to fungi of Madras - XVII. Proc. Indian Acad. Sci., B 41(5): 189-195.

Rangaswami G., Seshadri V. S. \& Lucy Channamma K. A. 1970. Fungi of South India. University of Agriculture Sciences, Banglore. 